\title{
PROGRESSION OF LIVER FIBROSIS IN MONOINFECTED PATIENTS BY HEPATITIS C VIRUS AND COINFECTED BY HCV AND HUMAN IMMUNODEFICIENCY VIRUS
}

\author{
Cristiane Valle TOVO, Smile Calisto da Costa BECKER, \\ Paulo Roberto Lerias de ALMEIDA, Bruno GALPERIM and Silvia CHAVES
}

\begin{abstract}
Context - The progression of liver fibrosis in patients coinfected by hepatitis $\mathrm{C}$ virus and human immunodeficiency virus (HCV/HIV) has been increasingly studied in the past decade. Studies made before the highly active antiretroviral therapy suggest that HIV can change the natural history of the HCV infection, leading to a faster progression of the liver fibrosis. Objective - To evaluate and compare the fibrosis progression in two groups of patients (HCV/HIV coinfected and HCV monoinfected) Methods - Seventy patients HCV monoinfected and 26 patients HCV/HIV coinfected who had not undertaken HCV treatment and were submitted to serial percutaneous liver biopsies were retrospectively evaluated. There was no difference in the fibrosis progression between the two groups. Conclusion - The fibrosis grade evolution was not worse in the coinfected patients. The immunosuppression absence and the shortest time period between the biopsies in the coinfected group are possible explanations.
\end{abstract}

HEADINGS - Liver cirrhosis. Hepatitis C, chronic. Hepacivirus. HIV infections. Coinfection.

\section{INTRODUCTION}

Major occurrence of fibrosis progression in patients coinfected with the hepatitis $\mathrm{C}$ virus $(\mathrm{HCV})$ and human immunodeficiency virus (HIV), when compared with those $\mathrm{HCV}$ monoinfected, has been indicated in some studies and refuted in others.

Many studies have shown that fibrosis progresses more rapidly in coinfected patients than in monoinfected patients, leading to increased rates of cirrhosis and complications $s^{(4,12)}$. A longitudinal study supported these findings, although the phenomenon of accelerated fibrosis is not universal, because progression of fibrosis by serial biopsies is highly variable ${ }^{(26)}$.

Most of the studies do not make serial hepatic biopsy evaluations, taking into consideration only the progression from the presumed infection date (generally the intravenous drugs user patients and those subjected to blood transfusions), considering this a critical point ${ }^{(4,6,9,14,16,17,20)}$.

The objective of this study is to, through two liver biopsies, evaluate and compare the fibrosis progression in coinfected HCV/HIV and HCV monoinfected patients who did not undertake treatment against $\mathrm{HCV}$, allowing for better observation of the fibrosis progression in this patient sample and contributing to a better resolution in this highly debated topic.

\section{METHODS}

A retrospective study was completed with $\mathrm{HCV}$ monoinfected and HCV/HIV coinfected patients who had not undertaken HCV treatment; patients were submitted to serial percutaneous liver biopsies in a tertiary care Public Hospital in the South of Brazil (and landmark to coinfected patient care), in the comprehensive period between January, 2007 and January, 2011.

The liver biopsies were performed in order to help decide whether or not to carry out treatment against the $\mathrm{HCV}^{(8)}$

The biopsies were percutaneous, in ambulatory regime. The patients should present the prothrombin time at the latest 3 seconds above the control and platelet count of at least $80.000 / \mathrm{mm}^{3}$. The material was fixed in paraffin, and the blades prepared with hematoxylin-eosin and Masson's trichrome. All the biopsies were evaluated by one pathologist only, committed to the Hepatology area, who was not informed if the coinfection was present or not. 
Sex, age, HCV genotype, CD4 cell count (in those coinfected), the time between the biopsies, and the fibrosis grade through METAVIR score ${ }^{(3)}$ were evaluated in both groups of patients.

\section{Ethic aspects}

The study was submitted to and approved by the Ethics Committee in Research of the Hospital Nossa Senhora da Conceição, Porto Alegre, RS, Brazil (approval number 11229).

\section{Statistics analysis}

For statistical analysis, the chi-square test with Yates correction was used for the variable categories and bicaudal Student's test for continuous ones. The significance level adopted was $5 \%$.

\section{RESULTS}

Seventy HVC monoinfected and $26 \mathrm{HCV} / \mathrm{HIV}$ coinfected patients were studied.

The general characteristics of the patients can be observed in Table 1.

TABLE 1. Patients characteristics

\begin{tabular}{|c|c|c|c|}
\hline & $\mathrm{HCV}$ & $\mathrm{HCV} / \mathrm{HIV}$ & $P$ \\
\hline Male gender - n (\%) & $27(38.6)$ & $14(53.8)$ & 0.18 \\
\hline Genotype 1 - n (\%) & $29(58.0)$ & $12(80.0)$ & 0.12 \\
\hline $\begin{array}{l}\mathrm{CD} 4 \text { (cells } / \mathrm{mm} 3) \text { - } \\
\mathrm{m} \text { (variation) }\end{array}$ & -------- & $641(279-1202)$ & --------- \\
\hline $\begin{array}{l}\text { Age (years) - } \\
\text { m (variation) }\end{array}$ & $49.4(27-72)$ & $40.8(26-59)$ & $<0.001$ \\
\hline $\begin{array}{l}\text { Break (months) - } \\
\text { m (variation) }\end{array}$ & $65(21-159)$ & $50(12-99)$ & 0.014 \\
\hline $\begin{array}{l}\text { No. PT in the biopsy - } \\
\mathrm{m} \text { (variation) }\end{array}$ & $5.67(2-15)$ & $6.14(2-15)$ & 0.22 \\
\hline
\end{tabular}

The coinfected patients were significantly younger. The interval time between the biopsies was significantly lower in the coinfected patients group.

There was not any statistical difference in the evaluation of gender, genotype and number of portal tracts between the two groups of patients.

All coinfected patients had CD4 cell-counts above 200 cells $/ \mathrm{mm}^{3}$, with a variation between 279 and 1202 cells $/ \mathrm{mm}^{3}$.

The aspects concerning the fibrosis progression can be observed in Table 2 . There was no statistically significant difference in regards to the fibrosis progression between the groups.
TABLE 2. Fibrosis evolution

\begin{tabular}{lcc}
\hline Fibrosis & $\begin{array}{l}\text { HCV } \\
\mathbf{n}(\%)\end{array}$ & $\begin{array}{c}\text { HCV/HIV } \\
\mathbf{n}(\%)\end{array}$ \\
\hline Progression & $31(44.3)$ & $07(26.9)$ \\
Stable & $32(45.7)$ & $17(65.4)$ \\
Regression & $07(10.0)$ & $02(7.7)$ \\
Total & $70(100.00)$ & $26(100.00)$ \\
\hline
\end{tabular}

$P=0.22$

Progression: patients who present a fibrosis progression of at least 1 degree Stable: patients who keep with the same fibrosis degree

Regression: patients who present a fibrosis regression of at least 1 degree

\section{DISCUSSION}

The HCV infection has an estimated prevalence of about $3 \%$ in the world, which represents approximately 170 million people chronically infected with $\mathrm{HCV}$, constituting a serious public health problem ${ }^{(1,24,28)}$.

The HCV/HIV coinfection is one of the most relevant infections in the HIV patient group, affecting about onethird of them ${ }^{(22,27)}$. The end-stage liver disease progression may occur faster in coinfected patients and the cirrhosis decompensation is the principal cause of hospitalization and death in this group ${ }^{(18,23)}$.

Some researchers concluded that fibrosis progression is time-dependent, and this estimation is important information concerning the vulnerability evaluation of a patient and the impact of the treatment on the disease's natural history ${ }^{(11)}$. Some factors are associated with major liver fibrosis progression in HCV patients: the infection time, the age when the infection was acquired, male gender, alcohol abuse, hepatitis $B$ virus (HBV) coinfection, the coinfection by HIV, and the high presence of alanine aminotransferase (ALT) ${ }^{(5,15)}$.

The cirrhosis progression may be more frequent in $\mathrm{HCV} / \mathrm{HIV}$ coinfected than in HCV monoinfected patients. In $\mathrm{HCV} / \mathrm{HIV}$ co-infected, the fibrosis progression is even faster, with an advanced degree of immunodeficiency. In addition to histological progression, the clinical progression to hepatic decompensation also seems to be accelerated in coinfected patients. These studies were mostly conducted before the HAART era, when a great impact in the morbidity and mortality in HIV infected patients was demonstrated ${ }^{(1,20)}$.

Recent studies in which only one liver biopsy was performed demonstrated that the patients using HAART have a slower liver fibrosis progression compared to those who were not treated ${ }^{(9)}$. Other studies, in which the conclusion was based in paired biopsies, did not find any relation between fibrosis progression and HAART, and sometimes even the opposite, clearly showing the greater viral load of HIV-RNA in HAART-naïve patients as a protection factor to deaths due to liver disease ${ }^{(19)}$.

One possible mechanism to explain the association between the HIV suppression and the fibrosis progression would be the HIV effect on fibrogenesis. In in vitro models, the inactive HIV increases the TGF-beta 1 expression both in $\mathrm{HCV}$ infected and non-infected patients. This cytokine is one of the principal mediators of hepatic fibrogenesis ${ }^{(2,21)}$. 
Most of the knowledge about liver fibrosis progression in $\mathrm{HCV} / \mathrm{HIV}$ coinfection derives from cross-sectional studies based on a single liver biopsy $y^{(9,24,27)}$. In these studies, the start date of $\mathrm{HCV}$ infection is usually estimated as the date of the first administration of injectable drugs. At the beginning of $\mathrm{HCV}$ infection, it is assumed that the patient had no liver fibrosis. Most of the HCV infection time was not observed, and the factors that could influence the fibrosis progression were collected only for a short period of time out of the whole progression of the HCV infection. Such presumed knowledge is probably one of the reasons for these conflicting study results, especially regarding the effect of HAART in the fibrosis progression.

A few studies observed the fibrosis progression through serial liver biopsies in coinfected patients ${ }^{(7,15,22,25,26)}$. The serial liver biopsies would present some advantages over the implementation of a single liver biopsy. Changes between the fibrosis stages could be observed between the two dates. In addition, the factors that could influence the fibrosis progression could be observed during the period between the biopsies, whilst the data is easier to be collected, along with a higher reliability ${ }^{(15)}$.

Macias et al. ${ }^{(15)}$ evaluated $135 \mathrm{HCV} / \mathrm{HIV}$ coinfected patients through two biopsies, with a time interval of at least 1 year between them (average 3.3 years), and observed that $17 \%$ had fibrosis regression; in 39\% the fibrosis remained unchanged; in $28 \%$ the fibrosis progressed 1 degree, and in $16 \%$ the fibrosis progressed at least 2 degrees. Factors related to the progression were HIV viral load, moderate/ severe necroinflammation in the first biopsy, the time period between the biopsies and the response to $\mathrm{HCV}$ treatment.

In this present study, $26.9 \%$ had fibrosis progression, $65.4 \%$ remained stable, and $7.7 \%$ had fibrosis regression. We can mention some limitations of this present study, such as the lack of informative data about the HAART use and HIV viral load, which could justify more or less fibrosis progression in the coinfected group. Furthermore, the time period between the biopsies was relatively short in regards to the observation of the occurrence of fibrosis progression.
In addition to these limiting factors, it is possible to consider that the group of patients that agreed to go through two biopsies and was included in the present study can be considered highly select, probably more adherent to the accompaniment, and perhaps not representative of the general population of mono and coinfected patients. All these described factors were also considered by Macias et al. ${ }^{(15)}$.

In regards to the quality of the liver fragment found in the biopsy, some samples showed a small number of portal tracts to the histopathology examination. However, given that the average and the standard deviation were similar in both groups, the analysis can be considered valid. Macias et al. ${ }^{(15)}$ and Sterling et al. ${ }^{(25)}$ described the size of fragment obtained, but not the number of portal tracts found.

Sterling et al. ${ }^{(25)}$ recently published a study evaluating 66 mono and coinfected patients who underwent serial liver biopsies. The time period between the biopsies was similar to the present study (5.8 and 4.7 years in mono and coinfected, respectively), and observed that the fibrosis progression was similar between the two groups. These authors suggest that patients should be submitted to serial liver biopsies in order to evaluate the fibrosis progression, in view of the fact that there are not any serum markers that could safely predict the patients' evaluation.

Nowadays, however, non-invasive methods such as Fibrotest, the aspartate aminotransferase-to-platelet ratio index (APRI), or hepatic elastography are being increasingly proposed to assess liver fibrosis progression in $\mathrm{HCV}$-monoinfected or coinfected HCV/HIV patients ${ }^{(10,13)}$.

\section{CONCLUSION}

The fibrosis grade evolution was not worse in coinfected patients. This study suggests, according to others conducted in the HAART age, that the hepatic fibrosis progression does not occur in an accelerated way in coinfected individuals when compared to monoinfected patients.

The immunosuppression absence and the shortest time period between the biopsies in the coinfected group are possible explanations to the data found in this study.

Tovo CV, Becker SCC, Almeida PRL, Galperim B, Chaves S. Progressão de fibrose hepática em pacientes monoinfectados pelo vírus da hepatite C e coinfectados pelo vírus da hepatite C e vírus da imunodeficiência humana. Arq Gastroenterol. 2013;50(1):19-22.

RESUMO - Contexto - A progressão da fibrose hepática em pacientes coinfectados pelos vírus da hepatite C (VHC) e da imunodeficiência humana (VHC/HIV) tem sido mais estudada na última década. Estudos realizados antes da terapia antiretroviral de alta potência (HAART) sugerem que o HIV pode mudar a história natural da infecção pelo VHC, levando a uma progressão mais rápida da fibrose hepática. Objetivo - Avaliar e comparar a progressão de fibrose em duas populações de pacientes (coinfectados VHC/HIV e monoinfectados VHC). Métodos - Foram avaliados retrospectivamente 70 pacientes monoinfectados VHC e 26 coinfectados VHC/HIV nunca tratados para o VHC e que haviam realizado duas biopsias hepáticas seriadas. Não houve diferença na progressão de fibrose entre os dois grupos. Conclusão - A evolução do grau de fibrose não foi pior nos pacientes coinfectados. A ausência de imunodepressão e o menor intervalo de tempo entre as biopsias no grupo de coinfectados são possíveis justificativas.

DESCRITORES - Cirrose hepática. Hepatite C crônica. Hepacivírus. Infecção por HIV. Coinfecção. 


\section{REFERENCES}

1. Alter MJ. Epidemiology of hepatitis C in the West. Semin Liver Dis. 1995;15:5-14

2. Balagopal A, Philp FH, Astemborski J, Block TM, Mehta A, Long R, Kirk GD, Mehta SH, Cox AL, Thomas DL, Ray SC. Human Immunodeficiency Virus-related Microbial Translocation and Progression of Hepatitis C. Gastroenterology. 2008;135:226-33.

3. Bedossa P, Poynard T. An algorithm for the grading of activity in chronic hepatitis C. The METAVIR Cooperative Study Group. Hepatology. 1996;24:289-93.

4. Benhamou Y, Bochet M, Di Martino V, Charlotte F, Azria F, Coutellier A, Vidaud M, Bricaire F, Opolon P, Katlama C, Poynard T. Liver fibrosis progression in human immunodeficiency virus and hepatitis $\mathrm{C}$ virus coinfected patients. The Multivirc Group. Hepatology. 1999;30:1054-8

5. Benhamou Y, Di Martino V, Bochet M, Colombet C, Thibault V, Liou A, Katlama C, Poynard T; MultivirC Group. Factors affecting liver fibrosis in human immunodeficiency virus and hepatitis $\mathrm{C}$ virus-coinfected patients impact of protease inhibitor therapy. Hepatology 2001;34:283-7.

6. Berenguer J, Bellón JM, Miralles P, Alvarez E, Castillo I, Cosín J, López JC, Sánchez Conde M, Padilla B, Resino S. Association between exposure to nevirapine and reduced liver fibrosis progression in patients with HIV and hepatitis $\mathrm{C}$ virus coinfection. Clin Infect Dis. 2008;46:137-43.

7. Bonnard P, Lescure FX, Amiel C, Guiard-Schmid JB, Callard P, Gharakhanian S, Pialoux G. Documented rapid course of hepatic fibrosis between two biopsies in patients coinfected by HIV and HCV despite high CD4 cell count. J Viral Hepat. 2007;14:806-11.

8. Brasil. Ministério da Saúde [Internet]. Portaria n ${ }^{\circ} 221$, de 13 de julho de 2011 Protocolo clínico e diretrizes para o tratamento da hepatite viral C. Available from: http://portal.saude.gov.br/portal/arquivos/pdf/pcdt_hepatite_c_2011_retificado.pdf

9. Brau N, Salvatore M, Ríos-Bedoya CF, Fernández-Carbia A, Paronetto F, Rodríguez-Orengo JF, Rodrigues-Torres M. Slower fibrosis progression in HIV/ HCV-coinfected patients with successful HIV suppression using antiretroviral therapy. J Hepatol. 2006;44:47-55.

10. DallaPiazza M, Amorosa VK, Localio R, Kostman JR, Lo Re V 3 rd. Prevalence and risk factors for significant liver fibrosis among HIV-monoinfected patients. BMC Infect Dis 2010;10:116-22.

11. De Torres M, Poynard T. Risk factors for liver fibrosis progression in patients with chronic hepatitis C. Ann Hepatol 2003; 2: 5-11.

12. Graham CS, Baden LR, Yu E, Mrus JM, Carnie J, Heeren T, Koziel MJ. Influence of human immunodeficiency virus infection on the course of hepatitis $\mathrm{C}$ virus infection: a meta-analysis. Clin Infect Dis. 2001;33:562-9

13. Macías J, Girón-González JA, González-Serrano M, Merino D, Cano P, Mira JA, Arizcorreta-Yarza A, Ruíz-Morales J, Lomas-Cabeza JM, García-García JA, Corzo JE, Pineda JA. Predicition of liver fibrosis in human immunodeficiency irus/hepatitis $\mathrm{C}$ vírus coinfected patiets by simple non-invasive indexes. Gut. 2006;55:409-14.

14. Macías J, Mira JA, López-Cortés LF, Santos I, Girón-González JA, González-Serrano M, Merino D, Hernández-Quero J, Rivero A, Merchante N, Trastoy M, Carrillo-Gómez R, Arizcorreta-Yarza A, Gómez-Mateos J, Pineda JA. Antiretroviral therapy based on protease inhibitors as a prospective factor agai nst liver fibrosis progression in patients with chronic hepatitis C. Antivir Ther. 2006;11:839-46.

15. Macías J, Berenguer J, Japón MA, Girón JA, Rivero A, López-Cortés LF, Moreno A, González-Serrano M, Iribarren JA, Ortega E, Miralles P, Mira JA, Pineda JA. Fast fibrosis progression between repeated liver biopsies in patients coinfected with human immunodeficiency virus/hepatitis C virus. Hepatology. 2009;50:1056-63.
16. Martín-Carbonero L, Benhamou Y, Puoti M, Berenguer J, Mallolas J, Quereda C, Arizcorreta A, Gonzalez A, Rockstroh J, Asensi V, Miralles P, Laguno M, Moreno L, Girón JA, Vogel M, García-Samaniego J, Nuñez M, Romero M, Moreno S, de la Cruz JJ, Soriano V. Incidence and predictors of severe lifer fibrosis in human immunodeficiency virus-infected patients with chronic hepatitis $\mathrm{C}$ : a European collaborative study. Clin Infect Dis. 2004;38:128-33.

17. Mehta SH, Thomas DL, Torberson M, Brinkley S, Mirel L, Chaisson RE, Moore RD, Sulkowski MS. The effect of antiretroviral therapy on liver disease among adults with HIV and hepatitis C coinfection. Hepatology 2005;41:123-31.

18. Pineda JA, Romero-Gómez M, Díaz-García F, Girón-González JA, Montero JL, Torre-Cisneros J, Andrade RJ, González-Serrano M, Aguilar J, Aguilar-Guisado M, Navarro JM, Salmerón J, Caballero-Granado FJ, García-García JA; Grupo Andaluz para el Estudio de las Enfermedades Infecciosas; Grupo Andaluz para el Estudio del Hígado. HIV coinfection shortens the survival of patients with hepatitis C virus-related decompensated cirrhosis. Hepatology. 2005;41:779-89.

19. Pineda JA, García-García JA, Aguilar-Guisado M, Ríos-Villegas MJ, Ruiz-Morales J, Rivero A, del Valle J, Luque R, Rodríguez-Baño J, González-Serrano M, Camacho A, Macías J, Grilo I, Gómez-Mateos JM; Grupo para el Estudio de las Hepatitis Víricas de la Sociedad Andaluza de Enfermedades Infecciosas (SAEI). Clinical progression of hepatitis $\mathrm{C}$ virus-related chronic liver disease in human immunodeficiency virus-infected patients undergoing highly active antiretroviral therapy. Hepatology. 2007;46:622-30.

20. Reiberger T, Ferlitsch A, Sieghart W, Kreil A, Breitenecker F, Rieger A, Schmied B, Gangl A, Peck-Radosavljevic M. HIV-HCV co-infected patients with low CD4+ cell nadirs are at risk for faster fibrosis progression and portal hypertension. J Viral Hepat. 2010;17:400-9.

21. Rotman Y, Liang TJ. Coinfection with hepatitis $\mathrm{C}$ virus and human immunodeficiency virus: virological, immunological, and clinical outcomes. J Virol. 2009;83:7366-74

22. Schiavini M, Angeli E, Mainini A, Zerbi P, Duca PG, Gubertini G, Vago L, Fociani P, Giorgi R, Cargnel A. Risk factors for fibrosis progression in $\mathrm{HIV} / \mathrm{HCV}$ coinfected patients from a retrospective analysis of liver biopsies in 1985-2002. HIV Méd. 2006;7:331-7.

23. Soriano V, Puoti M, Sulkowski M, Cargneld A, Benhamou Y,Peters M, Mauss S, Bräu N, Hatzakis A, Pol S, Rockstroh J. Care of patients coinfected with HIV and hepatitis C virus: 2007 updated recommendations from the HCV-HIV International Panel. AIDS 2007; 21:1073-89.

24. Souza AR, Tovo CV, Mattos AA, Chaves S. There is no difference in hepatic fibrosis rates of patients infected with hepatitis $\mathrm{C}$ virus and those co-infected with HIV. Braz J Med Biol Res. 2008;41:223-8.

25. Sterling RK, Wegelin JA, Smith PG, Stravitz RT, Luketic VA, Fuchs M, Puri P, Shiffman ML, Contos MA, Mills AS, Sanyal AJ. Similar progression of fibrosis between $\mathrm{HIV} / \mathrm{HCV}$-infected and $\mathrm{HCV}$-infected patients: analysis of paired liver biopsy samples. Clin Gastroenterol Hepatol. 2010;8:1070-6.

26. Sulkowski MS, Mehta SH, Torbenson MS, Higgins Y, Brinkley SC, de Oca RM, Moore RD, Afdhal NH, Thomas DL. Rapid fibrosis progression among HIV/ hepatitis C virus-co-infected adults. AIDS. 2007;21:2209-16.

27. Valle Tovo C, Alves de Mattos A, Ribeiro de Souza A, Ferrari de Oliveira Rigo J, Lerias de Almeida PR, Galperim B, Riegel Santos B. Liver Int. 2007;27:40-6.

28. World Health Organization. Hepatitis C global prevalence (update). Wkly Epidemiol Rec. 2000;75:17-28.

Received 30/5/2012 Accepted 10/1/2013 